\title{
Kernos
}

Revue internationale et pluridisciplinaire de religion grecque antique

$25 \mid 2012$

Varia

\section{Paolo Scarpi (éd.), La rivelazione segreta di Ermete Trismegisto. Vol. 2}

\section{André Motte}

\section{(2) OpenEdition}

Journals

Édition électronique

URL : http://journals.openedition.org/kernos/2097

DOI : 10.4000/kernos.2097

ISSN : 2034-7871

\section{Éditeur}

Centre international d'étude de la religion grecque antique

\section{Édition imprimée}

Date de publication : 26 octobre 2012

Pagination : 385

ISSN : 0776-3824

\section{Référence électronique}

André Motte, « Paolo Scarpi (éd.), La rivelazione segreta di Ermete Trismegisto. Vol. 2 », Kernos [En ligne], 25 | 2012, mis en ligne le 01 octobre 2012, consulté le 21 septembre 2020. URL : http:// journals.openedition.org/kernos/2097 ; DOI : https://doi.org/10.4000/kernos.2097

Ce document a été généré automatiquement le 21 septembre 2020.

Kernos 


\title{
Paolo Scarpi (éd.), La rivelazione segreta di Ermete Trismegisto. Vol. 2
}

\author{
André Motte
}

\section{RÉFÉRENCE}

Paolo SCARPI (éd.), La rivelazione segreta di Ermete Trismegisto. Vol. 2, Milano, Fondazione Lorenzo Valla/Arnoldo Mondadori Editore, 2011.1 vol. $13 \times 20,5 \mathrm{~cm}, \mathrm{XL}+651 \mathrm{p}$. (Scrittori Greci e Latini). ISBN : 978-88-04-60426-6.

1 Le premier volume de cet ouvrage a été recensé dans Kernos [23 (2010), p. 406-407]. Est concerné cette fois, en ordre principal, l'Hermès latin, représenté par deux traités : le célèbre Asclepius, adaptation latine d'un traité grec perdu, et le copieux traité d'astrologie Hermetis Trismegisti de triginta sex decanis, connu aussi sous le titre de Liber Hermetis, qui est une traduction latine assez tardive d'un original grec non conservé de l'époque hellénistique. Pour ces deux traités, - comme pour les autres parties de l'ouvrage qui les précèdent et qui vont être indiquées, - on a droit à une brève introduction, au texte original emprunté à une édition antérieure, à une traduction en italien et à des notes abondantes, qui sont toutes regroupées en fin de volume. Composent tout d'abord l'édition les fragments et opuscules suivants : 34 fragments et témoignages de précurseurs de l'hermétisme, un hymne de 10 lignes au Pantocrator, 5 extraits hermétiques d'un papyrus d'Oxford, quelques fragments extraits de papyrus Vindobonenses Graecae et un opuscule relevant de l'Hermès copte et intitulé De ogdoade et enneade, dont n'est donnée que la traduction en italien. Le volume débute par une abondante bibliographie et se termine par un index très développé des notabilia, auxquels sont ajoutés les noms propres. 
2 La matière de ce volume est évidemment plus marginale que celle du premier, mais elle offre un complément utile. Dotée d'une solide reliure, l'édition est à nouveau très soignée. Elle clôture un travail rigoureux et tout à fait digne d'éloge.

\section{AUTEURS}

\section{ANDRÉ MOTTE}

Université de Liège 